\title{
Perspektif Mahasiswa Perguruan Tinggi Swasta di Daerah Terhadap Perkuliahan Daring
}

\author{
Sumarwoto \\ Universitas Wisnuwardhana Malang
}

Received: 25 September 2020; Revised: 08 Oktober 2020; Accepted : 11 November 2020; Published : December 2020; Available online : December 2020.

\begin{abstract}
This study aims to identify the perspectives of students at private universities in the region towards online lectures. This study uses a quantitative approach with a survey method using google form with 140 respondents from various study programs. Data analysis uses descriptive statistics to describe or describe the data that has been collected. From the results that have been obtained, it can be seen that the constraints of students at private tertiary institutions in the regions have special characteristics, especially in internet connection. Most students live in areas with weak internet connections. This has an effect on the criteria for online media that are interested in private tertiary education institutions in the regions, namely using media that is efficient in quotas, does not need a strong network, and is easy to use.
\end{abstract}

\section{Keywords: Student Perspective, Online Lectures, Private Universities in The Region}

\section{Pendahuluan}

Perkembangan teknologi informasi

dan komunikasi telah memberikan pengaruh dalam dunia pendidikan di Indonesia khususnya dalam proses pembelajaran. Salah satu indikasi dari fenomena ini adalah adanya pergeseran dalam proses pembelajaran dimana interaksi antara pendidik dan peserta didik tidak hanya dilakukan melalui hubungan tatap muka tetapi juga dilakukan dengan media-media komunikasi seperti komputer, internet, dan sebagainya.

Sejak pandemi Covid-19 masuk di Indonesia, hampir seluruh aspek kehidupan terdampak oleh pandemi tersebut, tidak terkecuali dalam bidang Pendidikan. Untuk menghambat penyebaran Covid-19 Kemendikbud menginstruksikan kepada seluruh sekolah dan perguruan tinggi untuk 
melaksanakan kegiatan belajar mengajar melalui daring.

Perihal pembelajaran daring sendiri, sebenarnya sudah menjadi program dari Direktorat Jenderal Dikti bahkan ketika masih dalam naungan Kementerian Ristek Dikti. Setiap tahun Kementerian selalu memberikan stimulus pengembangan e-learning bagi perguruan tinggi baik PTN maupun PTS.

Menurut Romiszowski mengatakan bahwa saat ini terdapat ratusan perguruan tinggi maya yang menyebar di seluruh dunia. Data tersebut menunjukkan bahwa peminat pembelajaran online learning terus meningkat dari tahun ke tahun.

Peralihan model pembelajaran dari konvensional menuju pembelajaran online tidak semudah yang dibayangkan. Kesiapan belajar baik dari dosen hingga mahasiswa perlu dipertanyakan. Elearning merupakan suatu pengalaman belajar yang disampaikan melalui teknologi elektronika. E-learning menghubungkan peserta didik dengan sumber pembelajarannya yang secara fisik terpisah atau berjauhan tetapi masih dapat berkomunikasi, berinteraksi dan berkolaborasi secara langsung. Namun demikian tidak mudah mengubah kebiasaan dari pelajaran tatap muka menjadi pembelajaran daring.
Peningkatan peran dan keaktifan mahasiswa dalam penggunaan berbagai media dan teknologi demi suksesnya perkuliahan daring sangatlah dipengaruhi oleh persepsi (Nugroho, 2012). Hal ini dikarenakan persepsi merupakan proses penginterpretasian stimulus yang diterima oleh panca indera menjadi suatu pemahaman. Otak akan menerjemahkan stimulus yang diterima dari alat indera untuk menghasilkan pemahaman yang akan memengaruhi cara individu berperilaku atau menanggapi suatu stimuli.

Persepsi inilah yang kemudian akan menggerakkan mahasiswa untuk dapat mengatur dan mengelola dirinya dalam kegiatan perkuliahan daring. Lebih lanjut lagi, persepsi manusia didefenisikan sebagai hasil dari perbedaan sudut pandang dalam penginderaan. Ada yang mempersepsikan sesuatu itu baik atau persepsi yang positif maupun persepsi negatif yang akan mempengaruhi tindakan manusia yang tampak atau nyata Hal ini mengindikasikan bahwa setiap individu akan memiliki sudut pandang atau persepsi yang berbeda walaupun berada pada kondisi pembelajaran yang sama dikarenakan stimuli yang diterima mungkin berbeda dan diinterpretasikan dengan cara yang berbeda. 
Persepsi tidak hanya dipengaruhi oleh karakteristik objektif tetapi juga harapan dan pengalaman sebelumnya (Schunk, 2012). Ketika pembelajar memeroleh sebuah stimuli, mereka cenderung akan membandingkan dan mencocokkan stimuli tersebut dengan konsep atau pengalaman yang ada di memori. Dalam proses tersebut, mereka juga melakukan proses matching dengan harapan yang dimiliki atau gambaran ideal akan suatu kondisi atau situasi tertentu.

Salah satu alasan mengapa mahasiswa menjadi objek penelitian karena pada hakikatnya pendidikan adalah memberikan layanan belajar bagi mahasiswa. Maka dari itu sudut pandang mahasiswa perlu diperhatikan dalam melaksanakan evaluasi terhadap pelaksanaan pembelajaran.

Subjek dalam penelitian ini adalah mahasiswa dari perguruan tinggi swasta di daerah dari berbagai program studi. Masalah utama dalam penelitian ini antara lain apa saja masalah yang dihadapi mahasiswa perguruan tinggi swasta di daerah selama pembelajaran daring? Apakah mahasiswa perguruan tinggi swasta di daerah mampu menyesuaikan diri dengan model pembelajaran daring? Dalam pembelajaran daring masalah apa saja yang harus dilakukan evaluasi menurut perspektif mahasiswa perguruan tinggi swasta di daerah?

\section{METODE PENELITIAN}

Penelitian ini menggunakan pendekatan kuantitatif dengan metode survei. Penelitian deskriptif dipilih untuk memperoleh data hasil eksplorasi tentang persepsi mahasiswa dalam melaksanakan perkuliahan daring. Responden penelitian adalah mahasiswa disalah satu perguruan tinggi swasta di daerah.

Pengumpulan data menggunakan Google Form. Penggunaan Google Form dianggap lebih praktis dan ekonomis jika dibandingkan dengan bentuk survey lainnya. Jumlah responden yang berhasil mengisi data hingga batas waktu yang ditentukan sebanyak 190 responden dari berbagai program studi.

Langkah penelitian diawali dengan pembuatan instrument, pengumpulan data, analisis data dan pengambilan kesimpulan. Penyajian data melalui tabel, grafik, penghitungan rata-rata dan penghintungan prosentase. Analisis data menggunakan teknik statistik deskriptif. Statistik deskriptif adalah statistik yang digunakan untuk menganalisis data yang telah terkumpul tanpa bermaksud membuat kesimpulan yang berlaku untuk seluruh populasi (Sugiono, 2008). 


\section{HASIL DAN PEMBAHASAN}

Dalam penelitian ini, terdapat 190 responden yang terlibat dalam penelitian ini. Jumlah pertanyaan yang diberikan kepada responden. Sebanyak tujuh pertanyaan. Berikut ini dapat disajikan data dari 190 responden yang telah bersedia mengisi angket dalam penelitian.

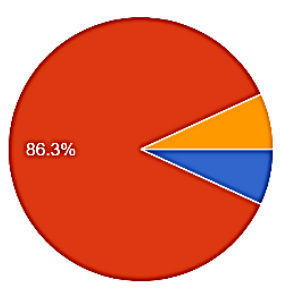

O Tidak Pernah

O Kadang-kadang

Selalu

Gambar 1. Mengalami kesulitan selama pembelajaran

Pada gambar 1 dapat diketahui sebanyak $86,3 \% \quad(164$ responden $)$ mengatakan kadang-kadang mengalami kendala setiap perkuliahan daring, sebanyak $\quad 6,8 \% \quad(13$ responden $)$ mengatakan selalu mengalami kendala setiap perkuliahan daring dan sebanyak 6,8\% (13 responden) mengatakan tidak pernah mengalami kendala pada setiap perkuliahan daring.

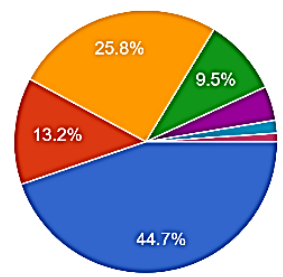

O Koneksi Internet

- Kuota Internet

Kurang Fokus

O Media Perkuliahan

- Tugas Kuliah

O Jadwal Perkuliahan

O Tidak Pernah

Gambar 2. Kendala yang paling dihadapi

Pada gambar 2 dapat diketahui sebanyak $44,7 \% \quad$ (85 responden) mengalami kendala koneksi internet, sebanyak $\quad 25,8 \% \quad$ (49 responden) mengatakan tidak focus dalam perkuliahan, sebanyak $\quad 13,2 \% \quad$ (25 responden) mengalami kendala pada kuota internet, sebanyak 9,5\% (18 responden) mengalami kendala pada media perkuliahan yang digunakan, sebanyak 4,2\% (8 responden) mengalam kendala pada tugas, sebanyak 1,6\% (3 responden) mengalami kendala pada jadwal perkuliahan dan sebanyak 1,1\% (2 responden) tidak pernah merasa ada kendala yang paling berarti selama mengikuti perkuliahan daring.
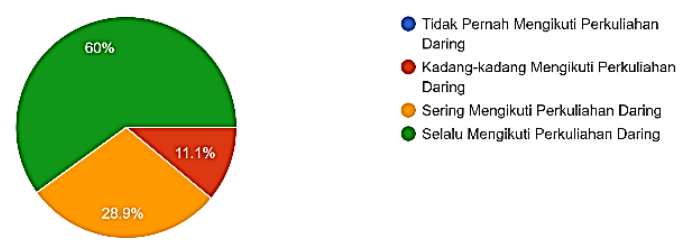

Gambar 3. Ketahanan mengikuti perkuliahan daring

Pada gambar 3 dapat diketahui sebanyak $60 \% \quad$ (114 responden $)$ 


\section{Jurnal Politik dan Sosial Kemasyarakatan \\ Vol 12 No 3 (2020) : Desember 2020}

mengatakan bahwa selalu mengikuti perkuliahan daring, sebanyak 28,9\% (55 responden) mengatakan sering mengikuti perkuliahan daring dan sebanyak $11,1 \% \quad$ (21 responden) mengatakan kadang-kadang mengikuti perkuliahan daring.

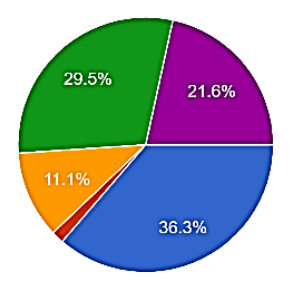

- WA Group

Google Class

O Zoom Meeting

- Google Meeting

Gambar 4. Media favorit dalam perkuliahan daring

Pada gambar 4 dapat diketahui sebanyak $\quad 36,3 \% \quad$ (69 responden) mengatakan bahwa media favorit mereka saat jadwal perkuliahan daring adalah whatsaap, sebanyak 29,5\% (56 responden) mengatakan zoom meeting menjadi media perkuliahan favorit, sebanyak $21,6 \% \quad$ (41 responden) mengatakan google meet menjadi media favorit mereka, sebanyak 11,1\% (21 responden) mengatakan e-learning moodle menjadi media favorit dalam perkuliahan daring dan sebanyak 1,6\% (3 responden) mengatakan google class menjadi media favorit mereka selama perkuliahan daring.

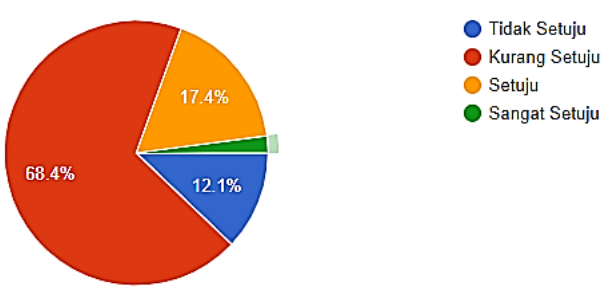

Gambar 5. Kenyamanan dalam pembelajaran daring

Pada gambar 5 dapat diketahui sebanyak $68,4 \%$ (130 responden) mengatakan kurang merasa nyaman dengan pembelajaran daring, sebanyak 17,4\% (33 responden) megatakan merasa nyaman dengan pembelajaran daring, sebanyak 12,1\% (21 responden) merasa tidak nyaman dengan pembelajaran daring dan sebanyak 2,1\% (4 responden) mengatakan sangat merasa nyaman dengan pembelajaran daring.

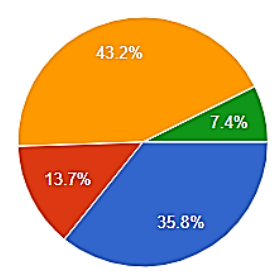

Media Daring (e-learning) O Jadwal Perkuliahan Koneksi Tidak ada

Gambar 6. Hal yang harus dievaluasi selanjutnya

Pada gambar 6 dapat diketahui sebanyak $43,2 \% \quad$ (82 responden) mengatakan koneksi menjadi bagian penting untuk di evaluasi, sebanyak $35,8 \%$ (68 responden) mengatakan perbaikan dan pembenahan media 
daring seperti e-learning perlu dilakukan, sebanyak $13,7 \% \quad$ (26 responden) mengatakan jadwal kuliah perlu mendapat evaluasi dan sebanyak 7,4\% (14 responden) mengatakan tidak ada yang perlu untuk dilakukan evaluasi dan perbaikan.
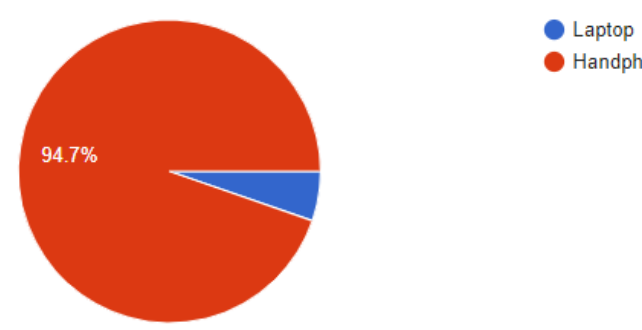
Handphone

Gambar 7. Perangkat yang dipakai perkuliahan daring

Pada gambar 7 dapat diketahui sebanyak $94,7 \% \quad(180$ responden $)$ mengatakan menggunakan perangkat handphone selama perkuliahan daring dan sebanyak 5,3\% (10 responden) mengatakan menggunakan laptop selama perkuliahan daring.

Dari hasil yang telah diperoleh dapat diketahui bahwa mahasiswa pada perguruan tinggi swasta di daerah memiliki karakteristik tersendiri dalam pelaksanaan perkuliahan daring. Ada beberapa hal yang dapat membedakan kendala yang dialami oleh mahasiswa pada perguruan tinggi swasta di daerah dengan perguruan tinggi swasta yang ada di kota-kota besar.
Kendala yang dihadapi mahasiswa perguruan tinggi swasta di daerah selama pembelajaran daring antara lain koneksi internet dikarenakan sebagian besar mahasiswa bertempat tinggal di daerah-daerah dengan koneksi internet yang lemah. Selanjutnya, mahasiswa kurang fokus dengan belajar secara online, kuota internet dan media daring yang digunakan sehingga Sebagian mahasiswa tidak dapat mengikuti pembelajaran daring dengan baik dan akhirnya sebagian besar mahasiswa akhirnya merasa tidak nyaman dengan perkuliahan daring. Meskipun mahasiswa sering mengalami kendala, namun tetap berusaha untuk mengikuti perkuliahan daring yang dilaksanakan.

Kriteria media daring yang disukai mahasiswa perguruan tinggi swasta di daerah adalah menggunakan media yang irit kuota, tidak butuh jaringan kuat, dan mudah digunakan. Oleh karena itu whatsaap menjadi media yang paling disukai mahasiswa. Selain itu, zoom meeting dan google meet menjadi aplikasi yang paling sering digunakan dalam video conference perkuliahan.

Masalah yang harus dievaluasi dalam pembelajaran daring menurut mahasiswa adalah metode pembelajaran, penggunaan media daring dari dosen, 
ketersediaan koneksi dan kuota internet mahasiswa.

Hal hal tersebut sejalan dengan pengamatan yang dilakukan oleh (Rachmawati et al., 2020) yang mengatakan banyak keluhan muncul dari para mahasiswa, seperti kendala sinyal, minimnya kuota paket data, banyaknya tugas dan minimnya penjelasan dari dosen. Para dosen juga mengeluhkan tentang tingkat partisipasi mahasiswa dalam kuliah, kendala sinyal dari mahasiswa serta sulitnya pembiasaan kuliah dengan sistem PJJ tersebut (Gunawan, Suranti, \& Fathoroni, 2020).

\section{KESIMPULAN}

Dari hasil yang telah diperoleh dapat diketahui bahwa kendala mahasiswa pada perguruan tinggi swasta di daerah memiliki karakteristik khusus, terutama dalam koneksi internet. Sebagian besar mahasiswa bertempat tinggal di daerah dengan koneksi internet yang lemah. Hal ini berpengaruh kepada kriteria media daring yang minati mahasiswa perguruan tinggi swasta di daerah adalah media yang irit kuota, tidak butuh jaringan kuat, dan mudah digunakan.

\section{Daftar Pustaka}

Gunawan, G., Suranti, N. M. Y., \& Fathoroni, F. (2020). Variations of models and learning platforms for prospective teachers during the COVID-19 pandemic period. Indonesian Journal of Teacher Education, 1(2), 61-70.

Nugroho, S. (2012). PROFESIONALISME GURU SD NEGERI SE-KECAMATAN WARUNGASEM KABUPATEN

BATANG Suatu tinjauan aspek persepsi guru tentang kepemimpinan kepala sekolah dan motivasi berprestasi guru. Jurnal VARIDIKA, 24(2).

Rachmawati, Y., Ma'arif, M., Fadhillah, N., Inayah, N., Ummah, K., Siregar, M. N. F., ... Auliyah, A. (2020). Studi Eksplorasi Studi Eksplorasi Pembelajaran Pendidikan IPA Saat Masa Pandemi COVID-19 di UIN Sunan Ampel Surabaya. Indonesian Journal of Science Learning, 1(1), 3236.

Schunk, D. H. (2012). Learning Theoriesan Educational Perspective.

Sugiono, P. D. (2008). Metode Penelitian Pendidikan Pendekatan Kuantitatif, Kualitatif, dan R\&D. Bandung: Alfabeta. 